\title{
PW01-001 - Pyrin-PSTPIP1 relation during cell migration
}

\author{
ZY Akkaya ${ }^{1 *}$, B Balci-Peynircioglu', A Cetinkaya ${ }^{1,2}$, N Purali $^{3}$, E Yilmaz ${ }^{1}$ \\ From 7th Congress of International Society of Systemic Auto-Inflammatory Diseases (ISSAID) \\ Lausanne, Switerland. 22-26 May 2013
}

\section{Introduction}

MEFV (MEditerranien FeVer) gene mutations cause Familial Mediterranean Fever (FMF). This gene encodes a protein termed as Pyrin, which appears to play an important role in the inflammatory pathways. It is far characterized that Pyrin, which is expressed in neutrophils, interacts with PSTPIP1 and actin proteins. In previous studies PSTPIP1 has been shown to interact with cell migration proteins and actin polymerization is a main force driving neutrophil migration. Therefore, we hypothesized that Pyrin can play role in cell migration through the interaction with actin and PSTPIP1.

\section{Objectives}

In this study, Pyrin-PSTPIP1 interaction was analyzed during cell migration. Our aim was to investigate whether these two proteins co-localize at the leading edge of the cell, where actin polymerization occurs.

\section{Methods}

A cell migration assay was generated using HL-60 cells. First of all, HL-60 cells were differentiated in to neutrophil like cells by using appropriate concentration of DMSO (DiMethyl SulfOxide). To test the efficiency of differentiation, neutrophil cell surface receptor FPR1 (Formyl Peptide Reseptor 1) gene expression levels were measured. Secondly, after differentiation, cells were stimulated for migration using fMLP (N-formyl-Met-Leu-Phe), a wellknown chemoattractant of neutrophils. The suitable fMLP concentration was determined by actin immunofluorescence staining. Neutrophil migration was demonstrated by using Live-cell imaging analysis. Lastly, un-differentiated, differentiated and differentiated-stimulated cells were co-stained for Pyrin-Actin, PSTPIP1-Actin and PyrinPSTPIP1 in order to test if the proteins localize together at the leading edge of the cell. Slides were analyzed by drawing profile and correlation curves with the help of confocal microscopy.

\section{Results}

The suitable concentration of DMSO for the experiment was $1,28 \%$ DMSO. In this concentration, FPR1 gene expression showed 165,89 fold increase $(\mathrm{p}<0,0021)$. After differentiation, cells showed $90 \%$ actin polymerization following 2 hours incubation with $150 \mathrm{nM}$ fMLP. In stimulated cells Pyrin-Polymerized actin, PSTPIP1-Polymerized actin and Pyrin-PSTPIP1 are found to be co-localized.

\section{Conclusion}

In differentiated and differentiated-stimulated cells, Pyrin was localized with actin and PSTPIP1 at the leading edge of the migrating cell. Also an interaction between PSTPIP1 and polymerized actin was shown. So far, PSTPIP1 was shown to localize rear of the cell, mostly in uropods. For the first time, PSTPIP1 was found to interact with dynamic actin and Pyrin at the site of polarization. Further studies on the effect of colchicine on this interaction during cell migration are under way. These data may contribute to understand the exact mechanism of cell migration through Pyrin-PSTPIP1 interaction.

\section{Disclosure of interest}

None declared.

Authors' details

${ }^{1}$ Medical Biology, Hacettepe University, Ankara, Turkey. ${ }^{2}$ Medical Genetics, Hacettepe University, Ankara, Turkey. ${ }^{3}$ Biophysics, Hacettepe University, Ankara, Turkey.

${ }^{1}$ Medical Biology, Hacettepe University, Ankara, Turkey

Full list of author information is available at the end of the article 
- Convenient online submission

- Thorough peer review

- No space constraints or color figure charges

- Immediate publication on acceptance

- Inclusion in PubMed, CAS, Scopus and Google Scholar

- Research which is freely available for redistribution 